\title{
Text: Literalism, Prophecy, and Authenticity
}

My Dad asked me a question when I was younger and he said to me, 'Karen how can you believe in the Bible? How can you believe that the Bible is true?' And I said, 'Well, you know, like I've been reading it, I've been taught it, and I think it is right.' And he said, 'Follow the history of the Jew ... [which is] God's story of His promises to a particular group of people and how he has maintained them throughout all the years against all odds.'

KAREN, 2013

When asked to explain what motivates their activities in relation to Israel, and why they believe that this is what God wants them to do, the volunteers always refer in one way or another to the Bible. The biblical promises to the Jews; the prophecies foretelling their return to the land; and God's covenant with the Jewish people collectively constitute the mandate upon which both the organizations' and the volunteers' self-understanding ultimately rests. This identity as a Bible-believing Christian was central in the transformative experience that was described in Chapter Three and it was further strengthened through the encounter with Israel and the possibility of experiencing God in the land, as described in Chapter Four. These biblical mandates, however, remain contested within various Christian contexts and the volunteers are often highly aware of alternative interpretations and the positions of theological opponents. In many cases, their own position is also contrasted explicitly with theological opponents who, they feel, do not take the Bible seriously. Tomas, encountered in the previous chapter, says, for instance:

Now when I, and I don't want to just say this as an opinion as well, because when I look at the Bible it's so clear that God has a plan, purpose and covenant. And so yes, I do completely disagree with Christians that have replaced Israel with the Church. It also reminds us that anybody can look at anything, or approach anything and twist it ... When I look at the Bible and God says that He has established an everlasting covenant, 
I believe that. Because it's a literal statement-why would I twist it and change it?

In the excerpt, Tomas argues that his view of the Bible's relationship to contemporary Israel should not be understood as "an opinion": a statement which exemplifies the literalist discursive dichotomy between literal readings and "interpretations" that is a highly salient feature of many biblically conservative communities. Simon Coleman, for instance, has remarked that "speakers" (preachers, Bible interpreters, witnesses etc.) in literalist cultures are not understood to be interpreting sacred text since

interpretation is opposed to disciplined speaking and hearing in the sense that it implies ambiguity of meaning in sacred text or inspired preaching - a result of the mind acting as distorting mediator between sacred language and receptive audience.

COLEMAN 2OO6, 49

"Interpretation", in this literalist discourse is often understood not as an inescapable component of textual engagement but rather as a superficial, ultimately unnecessary, and sometimes even dangerous practice that opens up a gap between the biblical text and God's intended meanings. While Tomas is recognizing the possibility of different interpretations of the covenant he also makes it clear that these alternative interpretations are invalid and distorting ("replacing", "twisting", and "changing"). His own reading is different: it relies on a "literal statement", the meaning of which is provided by the very wording of the text. This means that for most, if not all volunteers there is an objectively available "biblical view" of the land and of the conflict between the various groups that lay claim to it, one that is generally understood to be embodied in institutions like the ICEJ, the BFP, and the CFI. On the other side of the fence, representing an un-(or a-)biblical view are organizations like the United Nations, the World Council of Churches and large sections of the global Church which are understood to be under the spell of theological liberalism, so-called "allegorical hermeneutics", and "replacement theology".

1 Both "allegorical hermeneutics" and "replacement theology" are within quotation marks here because they refer to emic concepts; these are related to, but not identical with, allegory and replacement theology as the terms have more generally been understood within church history, biblical exegesis, or modern theologies. See below for further discussion about the local meanings attached to these terms. 
This chapter explores biblical literalism as it manifests within the Christian Zionist community in Jerusalem in relation to scholarly conversation about Evangelical textual ideology (Bielo 2015, Coleman 2006, Malley 2004). As we saw in Chapter One, biblical literalism has often been understood as a strict set of rules for textual engagement that explains Evangelical Zionist understandings of Israel. I believe this approach to be problematic not only because it simplifies the psychological, hermeneutical, and social processes involved in textual engagement but also because it naturalizes what is essentially an ideological claim. Instead, biblical literalism will here be understood as an ideological position of diverse, and at times ambivalent, interpretative possibilities. This textual ideology will be explored in two different yet interrelated areas that are central to the production of contemporary Evangelical Zionist identity: Bible prophecy and discourses about the "Hebraic roots" of Christian faith. It is argued that Bible prophecy is highly valued in what Malley has called "the quest for relevance" (2004), and that, in its retrospective form, it provides an epistemological framework that makes it logical to conceive of contemporary Israel as evidence for the truth of the biblical Scriptures. Yet the fundamental uncertainty of the future also leaves Bible prophecy unable to sustain, unassisted, the legitimacy of Evangelical Zionist readings of Israel. Further support for those readings is instead found through a reevaluation of early Christian history and Judeo-Christian identity. By employing historical narratives, contemporary Evangelical Zionists can subvert critical assessment of their faith and practices as modern manipulation of symbols and texts, and instead situate their religiosity as a rediscovery of an authentic biblical Christianity. In this reading, evangelical Zionism represents a direct continuation with Ancient Christianity as it was meant to be before it was eclipsed by Hellenism.

\section{An Ideology of Literalism}

Several anthropological studies have questioned the accuracy of Evangelical and fundamentalist claims to literalism as a description of actual interpretative practices and instead treated literalism primarily as an "interpretative tradition" (Harding 2000, 28, Malley 2004) or as a "language ideology or textual habitus" (Bielo 2015, 22, see also: Bielo 2009, Crapanzano 200o, Coleman 2006, Kaell 2014). Brian Malley, for instance, has described literalism primarily as an expression of theological and religious identity that separates adherents from ideological others. By identifying as a biblical literalist one also identifies what one is not (liberal, modernist, progressive etc.). As we saw from Tomas' interview excerpt, quoted above, such an identity is highly relevant in the Christian 
context in Jerusalem where arguments about "what the Bible says" are fundamental to broader arguments about the legitimacy of various historical narratives and theological positions as well as the distribution of political rights.

Literalism, however, is not only an identity marker. In several works it has also been shown to be closely associated with Protestant language ideologies in that it embeds assumptions about how language works and is supposed to work (Coleman 2006, Crapanzano 2000, Keane 2007, Bielo 2009). As a language ideology, literalism has been described as prioritizing the semantic and referential functions of language over pragmatic, performative, or contextrelating aspects (Coleman 2006). In such readings, Coleman has argued that "the meaning of a text is taken to be ultimately decidable, and traceable to original, authorial intention" $(2006,42)$. Coleman also notes, I believe correctly, that the ideology of literalism has certain parallels with modern linguistic ideology such as "certain assumptions about the relation of intention to meaning, the nature of speaking subjects and the relative importance of speakers over listeners in processes of semiosis" (2006, 42, see also: Stromberg 1993, Robbins 2001). Literalism then stresses a close relationship between language and reality, and the ability of language to accurately reflect inner states, intentions, and identities.

As James S. Bielo has recently noted, however, several scholarly accounts of biblical literalism have suffered from an overly negative rendering of the amount of creativity and interpretative flexibility that is available to interpreters in literalist cultures (2015). Perhaps the most influential example of this characterization of literalism is Vincent Crapanzano's Serving the Word: Literalism in America from the Pulpit to the Bench (2000). While recognizing literalism as a language ideology rather than a set of hermeneutic rules, there is little in Crapanzano's account of literalism, which he describes as characterized by a focus on "single, essential lexical meanings" and "unambiguous correlation between word and thing", that suggests that literalists might be capable of interpretative imagination and flexibility. In Bielo's words,

[Crapanzano's] approach also positions the literalist as a particular kind of textual user, defined by an either/or logic; having little tolerance for ambiguity, polysemy, or uncertainty; hemmed in by a strict originalist fidelity; and confined to the genre of the written text. In short, literalism in this scheme is a small, closed universe.

BIELO 2O15, 22

In sharp contrast to characterizations of literalism as "a small, closed universe" stand several ethnographic accounts which have highlighted the often 
ambiguous, flexible, and creative reading practices of conservative Evangelicals (Bialecki 2009, Bielo 2009, 2015, Johnson Frykholm 2004, Malley 2004). An important feature of such textual practices is the ongoing attempt to connect the biblical text to personal experiences. In the previous chapters we have seen how this feature of Biblicism is highly salient in Evangelical Zionism, not only in relation to personal lives (Chapter Three) but also in relation to the construction of Israel as a sacred space (Chapter Four). In previous literature a number of different frameworks have been suggested for this close association between the biblical text and everyday lives within Evangelicalism. Susan Harding (2000), drawing on the work of theologian Hans Frei (1974), has described such practices as being guided by a figurative logic which-in Frei's account - was the dominant mode of reading the Bible prior to the advent of modernity. Brian Malley (2004), of whom more below, describes literalist Bible reading practices as guided by a "search for relevance" which, while embedded in a rhetoric of literalism, still displays a large amount of flexibility in concrete textual engagements. Perhaps most telling is Bielo's own ethnographic account.

Bielo (2015) writes that it is his fieldwork among the creative artists designing the conservative Protestant theme park, Ark Encounter, that has forced him to "reassess literalism" $(2015,22)$ as something more similar to "a generative mode than a restrictive ideology" $(2015,32){ }^{2}$ In his account, "the paucity of scriptural detail" facing the creative artists trying to (re-)imagine and (re-)create a full-scale Noah's Ark "is not a straightjacket of confining limits; it is a bonanza of artistic opportunity" $(2015,32)$. The artists in Bielo's ethnography fill the textual gaps that emerge from Genesis' sparse account of the construction of the Ark by drawing on fictional textual resources including fantasy literature and art, graphic novels, contemporary Sci-Fi films as well as historic works.

Bielo's "recalibration" of literalism is also relevant for assessing the literalist culture in Jerusalem. Apocalyptic passages suffer a "paucity of scriptural detail" as well, and coherent eschatological narratives are only made possible by creative intertextual work. Often it is precisely in the more eschatologically oriented readings that Christian Zionism seems the most inclined towards figurative readings and the least bound by the letter of the text. It is also here that they are most likely to fill the textual gaps with super-textual material (such as geopolitical information, Religious Zionist ideology, prophecy fiction, and media representations of the Middle East) but, at the same time, it is in relation

2 Information about The Ark Encounter is available here: https://arkencounter.com/ (accessed 2019-o6-25). I generally share Bielo's critique of Crapanzano but I do not think that "ideology" necessarily needs to be understood as "restrictive". 
to these readings that a rhetoric about the legitimacy of literalism (and the illegitimacy of "allegory") plays the most crucial ideological role.

By approaching biblical literalism as a textual ideology I understand it both as a specific mode of approach involved in textual encounters and as a particular discursive location that needs to be defended and argued for. As Simon Coleman has remarked, "literalism has its own ambiguities and subtletiesindeed, its own subculture of interpretation - and there is very little that is simple about it" $(2006,58)$. With regards to Christian Zionism, this "subculture of interpretation" must be explored through a perspective that takes both tangible hermeneutical practices and broader ideological questions into account, and these questions need to be addressed in light of the literalist imperative, as well as the tensions and ambiguities that exist between literalism and prophecy belief.

\section{Ambiguities of Prophecy Belief}

In mid-spring 2013 I meet an older North American woman at the Shalhevetejah hostel, where I am staying during field work. Rachel is married to a Messianic Jewish Israeli and has lived in Israel for the past twenty years. Like many evangelicals in Jerusalem she feels that Christianity has lost touch with its Jewish roots, claiming that "we need to remove the paganism from the Church", a phrase often used in reference to Christian practices and holidays which, it is felt, do not have a clear biblical basis. Rachel tries to counteract this disconnection through the adoption of a limited kosher diet and the inclusion of a variety of Jewish and Messianic religious practices in her personal piety. After hearing about my research into evangelical Zionism, and my links to the three ministries in Jerusalem, she invites me to spend Friday evening with her, first in a Messianic congregation at Rehov Hanevim and later at a conference- "A World Turned Upside Down"-organized by the evangelical organization Intercessors for Israel.

Rachel was open and interesting, and during the evening she talked almost constantly_about the situation in Israel, about believers and unbelievers, about the situation for the Messianic congregations in Israel and the need for Israelis (Jews and Muslims) to realize who the Messiah is, and about Bible prophecy-not only to me but to everyone we met: the Ethiopian Falashas in the Messianic community, the taxi driver who took us to the conference, and other participants in the fancy hotel on Mount Scopus where the conference was held. The speaker for the evening was the Evangelical preacher Chuck Cohen, a prominent figure in Evangelical circles in Jerusalem who is related to the 
three ministries in Jerusalem in a variety of ways. That evening he discussed the spiritual economy that determines the distribution of God's "blessings" and "curses" and how the nations' relationships to Israel lie at the heart of this economy. In his speech, Cohen connected a new round of debates in the United Nations General Assembly to the "valley of Jehoshaphat" from Joel $3 .^{3}$

I will gather all the nations and bring them down to the valley of Jehoshaphat, and I will enter into judgment with them there, on account of my people and my heritage Israel, because they have scattered them among the nations. They have divided my land.

Cohen's interpretation of this passage suggested that contemporary debates in the UN should be understood as biblical events and that the countries that voted for a "division of the land" will be subjected to God's judgement. In the same sermon, Cohen was able to interpret several phenomena-which would, from a modern secular perspective, be viewed as discrete from each othersuch as the mass shooting at the premiere of Batman-The Dark Knight Rises, the Columbine Massacre, homosexuality, abortion, and the secularization of public schools, and explain them in the light of God's distribution of blessings and curses. In Cohen's reading, and presumably in that of many of his listeners, all these phenomena are connected through the eschatological narrative that situates them as the "birth pangs" (Mk. 13:8) that precede the coming of the Messiah; and all are in some way connected to how various other countries treat Israel. The root of all the "birth pangs", Cohen says, is "touching the Apple of God's eye": in other words, countries' voting against the Israeli position in the UN, criticizing Israeli political policies, or acting in a way that is felt to be contrary to Israeli political interests. While the disparate events discussed by Cohen sometimes feel completely random, their interpretation relies on an underlying logical structure known to participants at the conference. Such "eschatological guessing", writes Amy Johnson Frykholm, should be understood not as "random" but instead as "arising out of a coherent mythological structure ... The prophetic narrative ... lays out a formulaic series of events and characters. Believers do the work of filling in the blanks in order to understand and give shape to the world they live in" (2004, 120). Johnson Frykholm's point is that while the eschatological structure is strict, and often comes embedded in

3 At this time, the general assembly was debating whether to upgrade the status of Palestine in the United Nations from permanent observer to non-member observer state; a move that was viewed unfavorably by most Christian Zionists in Jerusalem. 
a rhetoric suggesting biblical literalism, actual reading practices show a great deal of flexibility and creativity.

Among the volunteers, Bible prophecy is generally understood as valid and meaningful in relation to Israel, and a general eschatological narrative guides interpretation of historical events, contemporary experiences in the land, and expectations, fears, and desires for the future. Yet Bible prophecy is a complicated topic and, in the following, I divide discourses concerning it into two parts since volunteers deal with prophecies in significantly different ways depending on whether they are understood to have been fulfilled, or are yet to come to pass.

\section{Prophecy: Past and Present}

As we have seen in previous chapters, the founding of the State of Israel and sociopolitical developments in Israeli history are generally understood in reference to already - at least partly — fulfilled prophecies. But the volunteers' own work in Israel is also often situated in this discursive context: by working towards Jewish-Christian reconciliation and by "blessing the Jewish people" the volunteers themselves become embedded in God's meta-historical labor, becoming characters in the prophetic narrative. For instance, Tom and Susan, an older American couple who are involved in a ministry's project involving elderly Israelis and war veterans, describe their work in reference to the biblical prophet Jeremiah. In their work they visit people in their homes, assess their needs, and collect stories that are later written down and published in the magazines and newsletters of the organization, to be distributed to members around the world. When I ask them about their work Tom describes it in reference to the ingathering of the exiles.

I mean that's the way the Bible says, "I will bring my people from the north and put them in the land." And so here is Jeremiah, he's looking far into the future and he sees these people coming from the north. And Susan and I, now in 2013, are sitting down at their table and having tea with these people that the prophet saw and we're talking to them. ${ }^{4}$

For Tom and Susan, this experience of sitting down and talking to the immigrants, collecting their stories and transcribing them for circulation is immensely spiritually fulfilling. Listening to them, I get the sense that these

4 This reference is generally drawn from Jeremiah $30-31$ where the return from captivity is prophesized in several different versions. The particular passage about the "north" occurs in Jer. 31:8. 
experiences are probably the major reason they keep going back and forth between Israel and their home country on a semiannual basis. While they seem genuinely happy to be able to help people in need, to make new friends from another country, and to record their stories, their work delivers an extra dimension of attainment by virtue of the fact that these people are not just anybody, but Jews that have returned to Israel in line with biblical prophecies. Every meeting with them testifies to the accuracy of those prophecies and it situates Tom and Susan as witnesses to the fulfillment of Scripture. The process of interpreting contemporary experiences through the biblical prophecies seems to close the gap between the biblical past and the volunteers' present. When Tom and Susan sit down around the coffee table to talk with the newly arrived Russian immigrants or elderly veterans of war they are experiencing the fulfillment of what the prophet Jeremiah "saw" millennia ago. They are experiencing the literal fulfillment of his words. It is almost "surreal", Tom says with a smile.

Biblical prophecy in this instance is figurative and retrospective. The ingathering of the exiles is a prophetic theme that is experienced as already (partly) fulfilled through the labor of the Zionist movement, immigration to Israel, and the social formation of the Israeli state. In its retrospective form, Bible prophecy is often utilized as a sense-making tool that imbues the volunteer work with transcendental meaning by figuratively connecting it to the biblical narrative. In Harding's ethnography of fundamentalist language (2000), she argues that Jerry Falwell's frequent use of figuration situates him alongside the biblical text, enabling him to assert a continuity between the biblical narrative and his own person. In doing so a double effect is produced: the continued relevance of the biblical text is defended and Falwell's own life becomes saturated with biblical meaning. What Tom, Susan, and other volunteers are doing is similar to Falwell in that it situates them as witnesses of the fulfillment of Jeremiah's ancient prophecies.

In addition to the personal importance attributed to witnessing the fulfillment of biblical prophecy by the volunteers, the figurative use of Bible prophecy also plays an epistemological role by serving as an evidence for the truth of the biblical Scriptures. This function of Bible prophecy has lately been observed in several studies of Christian Zionism (Spector 2009, Durbin 2013b, Smith 2013, Stewart 2014, 2015). Here the primary goal of Bible prophecy practices seems neither to be to interpret real world events in order to make them understandable, nor to produce political support for the State of Israel. Rather, it is to establish the connections between the Bible and historical experience as such, because this connection successfully produces the Bible as an inspired text, relevant to past, present, and future: prophetic evidence legitimizes the textual ideology of conservative Evangelicalism. The validity of 
this interpretation is repeatedly supported by the interview data. Karen, for instance, when asked about the "prophetic picture" and whether "it is important for her work in Jerusalem" replied:

Very. Very important. And that's the difference between ... other religions [that] I've done any research on and the one that I believe. I believe in the Bible, in the whole Bible ... My Dad asked me a question when I was younger and he said to me, "Karen how can you believe in the Bible? How can you believe that the Bible is true?" And I said, "Well, you know, like I've been reading it, I've been taught it, and I think it is right." And he said, "Follow the history of the Jew ... [which is] God's story of His promises to a particular group of people and how he has maintained them throughout all the years against all odds."

The "history of the Jew", and "his" survival "throughout all the years against all odds" here serves as an evidence that the biblical Scriptures are "true". This is a grand claim, but not an uncommon one. The story of Karen's father-here retold through the use of direct reported speech - bears close resemblance to a story that has often been repeated within both philo-Semitic and anti-Semitic circles: what Stephen Haynes has called the "Jews, your [sic] Majesty' legend" (Haynes 1995, 58). This is available in a multitude of different versions but it always involves one European ruler (Frederick the Great of Prussia, Louis XIV of France, Queen Victoria) and some sage (a court physician, the Christian philosopher Pascal, Otto von Bismarck, the Protestant preacher Furchtegott Gellert, the British Prime Minister Benjamin Disraeli). In the story the ruler asks the sage either if there is evidence of God, or how one can know that the Bible is true, and the sage always replies, "The Jew, Your Majesty". In Chapter Three we saw how direct reported speech could be used to displace responsibility for a particular claim that is being made in discourse. As Parmentier (1994) and others (Good 2007, Vincent and Perrin 1999) have argued, such use of reported speech can bolster the authority of particular claims since the authority of reported speech resides with the "original" speaker who is allegedly closer to the events being told. Karen here places the claim about the Jews' capacity to validate the truth of the biblical Scriptures with her father; in the "Jews, Your Majesty" legend this authoritative function is even more pronounced since it places the dialogue in a historical context and attributes it to a historical sage of either Christian or Jewish origin and a powerful ruler.

Haynes makes the point that the popularity of this story in both anti-Semitic, and philo-Semitic discourses testifies to the "Jews' signifying function" in the modern mind - and argues that this function positions the Jew as a "reluctant 
witness" to Christian truth (see also: Feldman 2007, 351, 366). Furthermore, the prevalence of the story in both spheres lends weight to Zygmunt Bauman's claim that the common root of both these phenomena is "allosemitism", the tendency to view the Jews as a cosmological Other (Bauman 1998, 2009). In Haynes' analysis of the role of the story he writes:

In its many variations, the "Jews, your [sic] Majesty!" legend is a postenlightenment version of a conviction that is deeply embedded in the Western (Christian) imagination: The Jews are a unique people and their dispersion, survival and very existence are a "miracle." For Christians the miracle of Jewish life has always indicated God's providential care. But in a deistic or agnostic environment where God's involvement with the world is not taken for granted, the Jews become invoked as proof of God's very existence.

Haynes 1995, 59

As can be seen from Haynes' argument, this "deeply embedded conviction" has long roots in Christian history and existed prior to the establishment of the State of Israel; thus it is not necessarily connected to beliefs in Bible prophecy in a strict sense. Nevertheless, since the establishment of the State of Israel it has increasingly become connected to its fate, not only among Evangelicals. ${ }^{5}$ Moreover, Haynes' description of the development of the Jews' signifying function is related, if not explicitly, to Frei's description of the changes in biblical hermeneutics following the advent of modernity (Frei 1974). The unity between the real world and the biblical text that previously could be pre-supposed now needed specific empirical evidence. In Karen's response to my question she paraphrases this legendary story to explain why Bible prophecy is important to her: it serves as a theological backdrop, an underlying logic against which the Jews' signifying function as a "witness-people" makes sense. ${ }^{6}$ By observing their history - the exile and the ingathering - through the lens of Bible prophecy it has become evident to her that the Scriptures are true. In other words, Jewish history, for Karen, serves as an index of a divine plan that guides the logics of history. Moreover, from her story it becomes clear that "reading it ...

5 Haynes discusses how the prominent Protestant theologian Karl Barth, for instance, "increasingly ascribed theological significance to the State of Israel" and that "Barth's theology of Israel evinces distinct parallels with classical Christian apprehensions of the Jews as witnesspeople" $(1995,78)$.

6 Since the Jews' signifying function is not necessarily connected to Bible prophecy other such theological backdrops, such as Augustinian theology or Karl Barth's theology is also possible, as Haynes shows. Within Evangelicalism however, Bible prophecy is the dominant mode. 
being taught it ... thinking it is right" is not enough. The "empirical evidence" provided solely and completely by the Jewish historical experience is necessary in order to "know" that the Bible is true.

\section{Prophecy: Future}

Amongst the volunteers, what I have here called "the retrospective form" of Bible prophecy is uncontroversial and generally accepted. It is rather in relation to the future that Bible prophecy becomes ambiguous and more difficult to handle. When questioned more specifically about Bible prophecy and the future, two (somewhat contradictory) conditions are simultaneously salient among the volunteers: (i) a general belief in the legitimacy of Bible prophecy in relation to Israel, and the assessment of prophecy beliefs as "biblical"; and (ii) a striking vagueness about eschatological detail and a stress on the ultimate unknowability of the eschatological future. This latter "eschatological agnosticism" is clearly exemplified by Jacob:

I don't know a lot of eschatological stuff, I really don't, I mean one minute I believe in the rapture, [chuckles] and the next minute I'm not sure about it. But you know what? One thing I do know is that God watches over this place and He is not going to let anything happen that shouldn't ... What do I see as the future here? I have no idea Aron. No idea. I don't know what it holds; I don't read a lot of that stuff, the eschatological and all that kind of thing because there are arguments for every side that I read. And I just get confused.

Prophecy belief is confusing, Jacob says, so he prefers not to dwell on it much. He seems fully content to focus on the present, leaving any future fulfillment of the biblical prophecies in the hands of God. But he is certain, he says, that God is in control, and that nothing will "happen that shouldn't". This eschatological agnosticism can also take different forms. Other Evangelical Zionists whom I have met approach the question of Bible prophecy with humor, or even keep an ironic distance, treating it as something that is fun to speculate or make jokes about, but nothing that should be taken too seriously (see also: Johnson Frykholm 2004, 109). In the pilot study that I did in 2011 I interviewed a Swedish Pentecostal who had enrolled in the IDF because he was committed to the idea that he had a calling to defend God's people (Engberg 2014). ${ }^{7}$ His approach to Bible prophecy is representative of this ironic tendency.

7 The interview was conducted in Swedish and the translation is provided by the author. 
[To] speculate ${ }^{8}$ [about biblical prophecy], oh, that is fun ... to sit down with a beer ... [with] your friends and you know talk ... God has given us the prophecies, there is a cause for that, but people go too much ${ }^{9}$ into detail.

Bible prophecy for this Pentecostal is presented as interesting, fun, to some extent important, but ultimately as something better dealt with in a bar than in the pulpit. It is an area for theological speculation rather than dogmatization; a "narrative mode of reading history" (Harding 20oo, 232). The relative distance maintained towards the various eschatological scenarios that are available in the Evangelical culture explored here is also shared by many of the volunteers; the stories, characters, and tropes are well-known but it is a matter of negotiation how they should be understood, and to what extent they are applicable to present-day contexts.

These agnostic and ironic relationships to future fulfillment of prophecy provide a sharp contrast to scholarly representations of the certainty with which Christian Zionists express their views about the end times. Several authors have recorded Evangelicals' descriptions of fairly elaborate scenarios of the future and how the coming apocalyptic cataclysm will play out (e.g. Clark 2007, Halsell 2003). Such views are, to some extent, represented amongst the volunteers, but to a much lesser degree than I expected when I first went out into the field. When I asked the volunteers about the future, some expressed more certainty than others about what to expect, including various well-known apocalyptic themes and tropes in their discourses such as "wars and rumors of wars" (KJV, Mt. 24:6, Mk. 13:7), a future third temple, and the arrival of the antiChrist. The future was often anticipated as dark, even dangerous, but with a silver lining suggesting that whatever comes, it will only be temporary. If Jacob among the volunteers can be seen to represent the most agnostic end of the "views of the future continuum", Sara is one of the more detailed and specific in her eschatological expectations:

I view that there's going to be greater and greater struggles ... We're going to have a false peace of course, when the anti-Christ comes to unite all the groups together and there's going to be an inter-faith happening on Mount Zion, right there where the Mosque of Omar is, we're going to have inter-faith. There's going to be this false peace-that's going to

8 Lit. "Theorize".

9 Lit. "a lot". 
happen. But before then I think there's going to be greater and greater turbulence and possibly even war for there to be, you know, a declaration of, "Ok, this is the peace agreement, let's go settle the issue." So I don't think it's going to get better for now.

Sara has fairly precise views of what is going to happen to Israel in the future: "a false peace", an "inter-faith meeting" on Mount Zion organized by the antiChrist, and "greater and greater turbulence", perhaps even wars. ${ }^{10}$ It is a bleak vision of a future where Israeli society is in a downward spiral of increasing violence and hostility, and where the relief from chaos comes only in the form of a "false peace": one that is bound to fail eventually since it is orchestrated by the anti-Christ. In its socio-historical pessimism and its emphasis on a false peace this vision comes close to many classic pre-millennialist scenarios where history is in a constant decline until Jesus returns to rapture the faithful and, later, to judge humanity and establish his millennial reign (Boyer 1992, Weber 2004). In spite of the dark picture of Israel's future, Sara expresses no fear for her own personal safety, but admits to being "anxious" at times, wondering how she would handle it if, or when, war breaks out. She describes how she was in Jerusalem during the IDF's operation, "Pillar of Defense", in November 2012 and heard the explosions of rockets launched from Gaza, an experience which "jolted" her "out of the surreal moment to reality". While saying that, out of concern for her family back home, she probably would not stay in Israel through a full scale war (as suggested by her future expectations); she also tells me that her expectations for the future make her work harder because she knows that time is short.

In relation to the textual ideology of biblical literalism, however, it is important to note that the apocalyptic themes in Sara's discourse are fairly loosely connected to the Bible and, arguably, might be drawn more directly from super-textual apocalyptic material (such as the Left Behind Series, or one of the many Evangelical commentaries on Bible prophecy) than from the biblical text as such. In a sense, the salience of these themes here testifies to the

10 The referent for "Mount Zion" has shifted during the history of Jerusalem. While today it usually refers to a hill just outside the Old City walls, it has previously been associated with the Temple Mount. The "Mosque of Omar", however, is not located on any of the hills that have been called "Mount Zion". Rather, it is a 12th century mosque just next to the Holy Sepulcher in the Christian quarters of the Old City. It is a reasonable guess that Sara is confusing the "Mosque of Omar" with either the al-Aqsa mosque, or the Dome of the Rock on the Haram al-Sharif/Temple Mount area since this usually holds a central place in Christian Zionist imaginaries. 
generativity of these genres, and how literalism can function more as a starting point for cultural work, than as a "straightjacket of confining limits" (Bielo 2015,32 ). In her ethnography of readers of the Left Behind Series, Amy Johnson Frykholm describes how this genre of literature is meant (by its authors) to convey biblical truth through the use of fiction (2004, see also: Maddux 2010). By translating the prophetic passages of the Bible into a fictional narrative that then is "placed back onto the biblical text" readers come to recognize the fictional themes as the "plain meaning" of the Bible. For instance, Sara's vision of an inter-faith meeting orchestrated by the anti-Christ is a theme that one might argue has taken this detour through the apocalyptic narratives of prophecy fiction before resurfacing here in the form of scriptural truth. The understanding of the anti-Christ as a unique individual who is the physical embodiment of the anti-thesis Christ and who will play a crucial role in the eschatological future (as opposed, for instance, to 1st and 2nd John's "anti-Christs" in plural that exist in the present) is also a central feature of the genre of conservative Christian fiction. So is the emphasis on an "inter-faith" meeting that ends in a "false peace" between Israel and the world.

Kathleen Boone has pointed out that it is ironic that extensive commentary is of such great importance in fundamentalist movements that are so deeply wedded to the authority of the text (1989). In relation to Bible prophecy, such commentaries have been of immense cultural importance, in the form of the Scofield Reference Bible, theological works, and later prophecy fiction. Yet the simultaneous occurrence of these two phenomena-an ideology of literalism and extensive commentaries - within the same cultural field is only ironic in so far as being wedded to the authority of the biblical text is understood as confining or limiting the possibilities for theological or cultural work. As Bielo has convincingly argued, literalism — understood as a generative mode — need not function that way (2015). While the biblical text is understood as authoritative (inspired), it also has gaps that leave plenty of room for intertextual work and creative imagination. Evangelicals, like other readers, are not bound exclusively to the Bible but rather draw from a variety of different texts to make sense of their faith and practices, some of which are invested with considerable authority. Such "textual economies" (Bielo 2009, 110-111) are also visible when it comes to Bible prophecy. In so far as intertextual work takes its departure from a "literalist imperative" it is still often understood by conservative readers to represent the literal meaning of Scripture, or at least a good guess that might be shown to be correct - or incorrect-in God's own time. Arguably, the genre of Protestant Bible prophecy has, at least for the past hundred years, existed almost completely in the intertextual gaps that are the consequence of the combination of both a literalist imperative and the impulse to mold a coherent 
historical narrative (covering past, present, and future) out of a disparate and heterogeneous textual mass. ${ }^{11}$

One final important point about the ambiguities surrounding the relationship between Bible prophecy and local literalist ideology among the volunteers comes from the interview with Tom and Susan, the American couple introduced above. In the excerpt they discuss a common theme-the expected future expansion of Israel's territorial borders - with a rhetoric suggesting certainty, and yet with a surprising vagueness with regards to the particularities of their vision.

T: Well, the borders yes, they're specified [in the Bible] too, and they're much greater than they are right now. So some day, I don't know whether that will be before or after Messiah comes, but the land will be, the land of Israel will be bigger than it is now. It says it will stretch from the Euphrates to what? The river of Egypt or something. So it ...,

S: It does upset us. We don't like to see them giving up any of their land, you know. It's just, it's yeah ... It upsets us. ${ }^{12}$

The future borders are "specified [in the Bible]", Tom says, but he is uncertain where the (south-western) border will be, and more importantly, he confesses that he does not know if this expansion will take place in historical times or in the post-Parousian future. This, of course, is a temporal distinction which has been central to much prophecy debate throughout the 19oos, and which can be seen to represent a central conundrum of Evangelical Zionism: to what extent, and in what ways, is the present separated from the millennial era? As we saw in Chapter Two, this question is also related to ideas about social agency. If there is a complete separation, as in classic formulations of dispensationalism, there is really no reason to believe that any kind of social or political action in the present can have an impact on the future. In other words, whether Israel "gives up land" in the present or not should not really matter, at least not from a theological point of view. Yet, despite her husband's uncertainty, Susan says

11 It has been noted, for instance, that dispensationalism can be viewed as an ambitious attempt to unify the different parts of the Christian Bible into one singular historical narrative, from creation until the end of times (Markham 2009).

12 Tom's reference is to Gen. 15:18: "On that day the LORD made a covenant with Abram, saying, 'To your descendants I give this land, from the river of Egypt to the great river, the river Euphrates'”. 
that when Israel gives "up any of their land" it upsets them, as if these borders are of utmost importance for the eschatological future..$^{13}$

The point here is not to highlight Tom and Susan's fairly limited attention to geographical, theological, eschatological, or political detail: that they do not know what they are talking about. Indeed, logocentrism can be an ethnographic problem (Michael Lambek in Kidron 2009, 20) and ethnographers often risk expecting their interlocutors to be more eloquent, coherent, and able to verbalize their thoughts and experiences than can realistically be expected. Thus it is important to be careful here. Yet, both with regards to the fundamental explanatory role apocalyptic theology-particularly premillennial dispensationalism - has been given in extensive previous research on Christian Zionism, and the rhetorical force with which it is insisted that certain views are rooted in the Bible, the "eschatological agnosticism" of the volunteers and the inattention to detail do seem somewhat surprising. If Bible prophecy is constitutive of the social worlds of Evangelical Zionists, and Bible prophecy is unanimously evaluated as "biblical" by the volunteers, would it not be reasonable to expect a little more precision about the eschatological details: How does contemporary Israel relate to the millennial Kingdom? Whatif anything — needs to happen before Jesus returns? Will there be a rapture of the faithful; a third temple on the Haram al-Sharif/Temple Mount? Does Israeli territorial expansion - or land concessions - in the present have an impact on the ways in which the eschatological future will play out? With regards to all these questions the volunteers often seem strangely undecided and commonly combine references to a few well-known apocalyptic tropes with a general emphasis on the fundamental impossibility of knowing the future. Yet, in the midst of all this uncertainty and negotiation, they still emphasize regularly and forcefully that their views - despite their imprecision — are the outcome of a literal reading of the Bible: that they are based on what the "Bible says".

\section{Bible Prophecy as an Interpretative Tradition}

The situation outlined above: the simultaneous appearance of a rhetoric of literalism and a general belief in the legitimacy and importance of Bible prophecy, combined with an eschatological agnosticism, suggests that Bible prophecy among the volunteers comes close to what Brian Malley has described as an

13 It should be noted that Susan's indignation over Israeli land concessions is not generally shared. Some volunteers argue that Israelis need "to make their own decisions" (Ruth 2013) without being guided by Evangelical prophetic speculation; some express concerns about Evangelical Christians who treat the Israelis as "a means to an end" (Anna 2013); and most clearly state that these things are ultimately beyond human knowledge. 
"interpretative tradition" (2004). In his How the Bible Works Malley has developed what he calls an "empirical model" of Evangelical Bible interpretation based on his observations in an American conservative Baptist church. This model involves four components: (i) Evangelical literalists have an "interpretative tradition" in which beliefs are attributed to the Bible with the goal of establishing "transitivity" between the text and cultural, theological, and moral beliefs; (ii) they do not have a "hermeneutic tradition" (an explicit set of rules that guide interpretative practices) that they employ systematically; (iii) Evangelical Bible reading is driven by a "search for relevance"; and, (iv) the interpretative tradition is caught between "the Scylla of interpretative freedom and the Charybdis of irrelevance" (2004, 73-74). The challenge for Evangelical reading practices, according to Malley, is to navigate between these two poles: to allow a certain amount of interpretative freedom in order to be relevant for individual lives yet not too much and thereby risk violating the interpretative tradition.

Malley understands the Evangelical interpretative tradition as a set of beliefs which is rationalized by reference to the (biblical) text. Establishing those connections, he emphasizes, can well be done even without access to a hermeneutical system. In fact, the absence of such a system might be beneficial in the quest for relevance.

Given the general principle that doctrines are somehow connected to the Bible, and as absence of formal rules to determine those connections, the interpretative tradition can harness Evangelicals' hermeneutic imagination anew in every generation.

MALLEY 2004, 101

One might question Malley's sharp distinction between "interpretative" and "hermeneutic" tradition and argue that an explicit and coherent theory of textual engagement is a common feature of elite circles, not of religious cultures in general. Conservative Evangelicals are hardly alone in this sort of nonformalized reading practice. That however, is not the point here. Rather, what Malley demonstrates about the interpretative tradition is how this "lack" of formal — and explicit—rules, together with the general principle that the Bible is able to explain all human beliefs and experiences, creates an environment that successfully stimulates the "quest for relevance" and produces the Bible as a sacred text. Maintaining a reasonable amount of interpretative freedom and individual hermeneutic creativity is key in this process:

Too much interpretative freedom and the tradition disintegrates, loosing [sic] its epistemological appeal; too little interpretative freedom and 
the Bible becomes merely an irrelevant historical artifact, rather than the ever-living word of God.

MALLEY 2004, 123

In relation to the discussion about Bible prophecy there is much to learn from Malley's model. It suggests, for example, that whether a belief is experienced as "biblical" is less a matter of actual exegesis than of whether the belief is possible to connect to the text in a way that is relevant for the scriptural community. Malley argues that Evangelical reading practice "emphasizes the fact of connection [between the Bible and beliefs] more than of particular connections", which, according to him, means that "a great deal of what the "Bible says' may be transmitted quite apart from actual exegesis" (2004, 73, emphasis in original). This explains why inattention to detail and the absence of a systematic eschatological narrative does not prevent these statements becoming, nevertheless, embedded in a rhetoric suggesting biblical literalism. Since the eschatological narrative common among Christian Zionists has already established a connection between the redemptive drama and the State of Israel, and since this narrative is understood as the biblical narrative, particular interpretations can safely be speculative, incomplete, even inconsistent, yet experienced as "biblical" insofar as they do not threaten to undermine the interpretative tradition or other core Evangelical beliefs. ${ }^{14}$

But eschatological speculation seems to make a more positive contribution to the interpretative tradition as well, significantly contributing to "the search for relevance". One area in which this aspect is particularly visible is in the figurative readings that connect biblical referents to historical events (and by doing so, effectively biblicalize cultural, political, and theological beliefs). In Christian Zionist literature and preaching such as that at the Intercessors for Israel conference described above, as well as in the interviews with the volunteers, it is very common that descriptions of the situation in Israel/Palestine, the peace process, the work of the organizations, or geopolitics is general are linked to scriptural passages in a way that directs attention to how a

14 Arguably, this was precisely what happened in the controversy that surrounded the publication of John Hagee's In Defense of Israel (2007) in which Hagee was accused of propagating a dual covenant theology. In the book Hagee criticized Christian supersessionism by arguing that Jesus never intended to be the Messiah to the Jewish people, which was understood by some Evangelical critics as Hagee questioning Jesus universal mission. After severe criticism Hagee had to publicly deny that he was teaching dual covenant theology and subsequent editions of the book changed the controversial passage (Shapiro 2011). 
particular event fits into the more general eschatological narrative. To return to the example quoted above: What is of importance is not whether all Evangelical listeners agree with Chuck Cohen's interpretation of particular events, and how they fit into God's economy — not all do, which becomes apparent in later interviews with volunteers-but rather how Cohen's examples taken together contribute to the (re-)production of a general prophetic narrative which places Israel at the center of historical causality. While listeners might disagree on whether the mass shooting at the Batman premiere should be read as a sign of divine intentionality, they might agree that the general spiritual causality explained by Cohen is accurate. Whether particular expectations or prophecies can be shown to be true or not is not necessarily the most important thing; the very possibility that they are true is enough to create the sense of urgency, relevance, and moral indignation that is sought. ${ }^{15}$

Similarly, in the organizations' literary productions Mordechai's words in Esther 4:14- "for if you keep silence at such a time as this" (my emphasis)frequently accompany new developments which the organizations deem to be in crucial need of community response: such as a new round of violence between Israel and Hamas, an EU decision to change the label for products produced in the territories outside the green line, terrorism, or anti-Semitic violence. What is curious about those readings and the way in which biblical texts are used is how they are able to continue to meaningfully speak to a particular situation despite the fact that they are being used over and over again in different contexts, times, and situations. For the Evangelicals involved in these practices, it does not seem to matter that these biblical tropes have continually appeared in Christian Zionist discourse over the past hundred years and nor does it matter that the "valley of Jehoshaphat" is invoked every time there is a new round of debate about the two-state solution or the peace process. While the semiotic content of the phrase "at such a time as this" and the biblical context in which it occurs seem to suggest that the present is a particularly crucial moment in God's timetable, discursive practices and the frequency with which the phrase is put to use suggest a slightly different interpretation: for the ministries in Jerusalem, it is always "such a time as this". 16 These textual practices come rhetorically embedded in an ideology of the "single, lexical meanings"

15 A similar discourse, by Pastor John Hagee, has been analyzed by Sean Durbin as a contemporary "Jeremiad" discourse, a moral critique of the US (Durbin 2013a, see also: Harding 2000).

16 Since 2012, the phrase "such a time as this" has occurred about 4 times per year in the newsletters from the ICEJ, BFP and CFI combined, which seems to suggest that the phrase is fairly regularly invoked when new developments are felt to prompt a Christian 
(Crapanzano 2000, 2-3) of biblical literalism but the discursive practices rather suggest a high degree of flexibility, contingency, polysemy, and creativity. What Susan Harding called the fundamentalists' "flexible absolutism" (2000, 275 ) is also applicable here: the fact that biblical referents are put to theological and ideological use, and that this usage changes over time, does not prevent them from becoming embedded in a rhetoric of literalism. Yet, as Webb Keane has argued, since processes of entextualization and (re)contextualization "exist in a dialectic relationship to each other", neither of the contexts of the utterance (biblical or contemporary) can serve as final arbiter in the analysis (Keane 1997b). Instead, the frequent (re)contextualizations of Mordechai's words in a new place and time should be seen as a discursive practice that simultaneously (re)connects listeners to the biblical past (and the sense of importance and urgency that the phrase conveys) and one that makes the biblical texts relevant by demonstrating their applicability in the present. By rhetorical practices such as these, the prophetic interpretative tradition can "harness Evangelicals' hermeneutic imagination anew in every generation" (Malley 2004, 101). ${ }^{17}$

Following Malley's description of an interpretative tradition, and given the forms that Evangelical eschatological thought takes in contemporary Jerusalem, Bible prophecy — dispensationalist or otherwise-appears less as a systematic configuration of beliefs than as a field of reference: a textual universe where particular connections between the biblical Scripture and real world events are made possible. For those so inclined (which, as can be seen above, is not everyone), this field can function as a "generative mode" (Bielo 2015,

response. For more about Christian Zionist reading of this particular verse see Durbin (2012).

17 One might be reminded here about the theory of the "cognitive dissonance" - first articulated by Festinger et al. in their 1956 study of "the Seekers" (Festinger, Riecken, and Schachter 1956) - that suggests that apocalyptic movements need to utilize different strategies to cope with the failure of prophecy. To connect a particular round of debate to the valley of Jehoshaphat, after all, is a prediction of sorts in that it suggests the approach of divine punishment to the countries that vote for a "division of the land". Nevertheless, I do not think that cognitive dissonance is particularly applicable here since these pronouncements are not presented (by speakers) or received (by listeners) primarily as falsifiable predictions of the future but rather as moral judgements of political positions and as an incentive for political (and spiritual) action. The sense of urgency and spiritual importance that these connections between biblical tropes and contemporary events create does not suffer from the "cry wolf" effect simply because they do not follow a hypothetical-deductive logic. They are "Kairos moments" that draw listeners into a scriptural universe, and situate them as moral actors in a redemptive drama. "For such a time as this" listeners are called to pray, contribute financially, and to take political action. 
32) that invites intertextual labor and apocalyptic speculation about the endtimes, the identity of the anti-Christ, and the connections between biblical symbolism and contemporary geopolitics (Johnson Frykholm 2004). But even for volunteers not particularly interested in apocalyptic speculation, such as Jacob for instance, the field of Bible prophecy contributes to the production of the sense of importance, urgency, and contemporary and personal relevance which are common features of Evangelical Zionist thought. Bible prophecy is fundamental to the identity of the volunteers as characters involved in God's historical project to restore the Jewish people to their land. It contributes to a sense of historical mission and importance, and it is highly spiritually fulfilling, as we saw in Tom and Susan's discourse above.

These features of the Evangelical scene in Jerusalem lead to a conclusion which is slightly different from that of much historical work on Bible prophecy and Christian Zionism to date (e.g. Gunner 1996). The heterogeneity and imprecision of this field is not necessarily only an outcome of insufficient attempts at systematization by leading figures, or the adaptation of theology to constantly changing historical realities (although these certainly play their part), but perhaps also a by-product of the more general structure of Evangelical Bible reading practices as such. Since these practices are geared towards the production of personal and contemporary relevance - "to make the Bible come alive" - and since they require a certain amount of interpretative freedom, apocalyptic thought constantly challenges the boundaries of the Evangelical interpretative tradition. Because these hermeneutic practices connect the biblical text to contemporary events, framing them in an eschatological narrative, they are highly beneficial in the quest for relevance, as the appeal of Israel-centered theologies testifies, but less so in terms of creating a systematic belief tradition. In their wake, Israel-centered theologies emerge less as a dogmatic system and more as a bricolage assembled from an assortment of biblical narratives, Israeli nationalism, extra-biblical apocalyptic fiction, and sometimes flamboyant apocalypticism: as theological drama rather than systematic theology. Nevertheless, in spite of this theological heterogeneity and imprecision, or perhaps because of it, the prophetic view of Israel becomes a linchpin in the quest for relevance, and consequently a central factor in the development of personal faith for these volunteers.

Bible prophecy, however, is not the only area in which Evangelical textual ideology surfaces in relation to Israel. In the final part of this chapter I discuss a more recent development within Evangelical Zionist thought which, to a certain extent, eclipses the previously dominant focus on Bible prophecy: discourses about the historical roots of Christianity, and Christianity's dependence on earlier Jewish tradition (see also: Durbin 2013b, Engberg 2012, Kaell 2015). 
This development towards a more comprehensive historical consciousness is a consequence of a willingness to theologically distance themselves from the more radical expressions of dispensationalism, the development of closer cooperation between Christian and Jewish Zionist organizations in Jerusalem and abroad, and perhaps also recognition that the ambiguities of prophecy beliefs makes them insufficient to function institutionally as an ideological basis. ${ }^{18}$ The turn towards history is guided by a search for the "Hebraic roots" of Christian faith, an authentic form of Christianity that pre-dates the Hellenization of the Jesus movement during the second and third century CE.

\section{Hebraic Roots of Christian Faith}

In February 2013 I was invited to take part in a full-day "foundational teachings" seminar at the Bridges for Peace headquarters in Jerusalem. This is a daylength lecture series that all volunteers at BFP are expected to go through some time during their stay in Jerusalem in order to be instructed in the theological framework of the organization's work, better equipped to act as "ambassadors" for Israel upon their return to their home countries, and empowered to speak for Israel ideologically as well as theologically. The teaching series is divided into five lectures: "Why Israel"; "The Hebraic Roots of Christian Faith"; "Israel and Bible Prophecy"; "Christian anti-Semitism"; and "Partakers of the Root". Taken together the lectures neatly sum up BF P's theological platform. ${ }^{19}$ While all the lectures were highly interesting and would warrant a discussion in themselves, particular focus is here given to the second lecture covering the theme of Hebraic roots, since it is here that the production of textual identity on the basis of historical narratives becomes most visible. Before turning to

18 This latter point is made explicit in an interview with David Parsons of the ICEJ where he argued that eschatological speculation is insufficiently stable to function as the theological basis of a large scale Christian ministry.

19 The lectures follow a pre-decided format and are delivered by different leaders at the organization. When I attended the event, four lectures $(1,2,3$, and 5$)$ were delivered by Cheryl Hauer and one (4) by Peter Fast. I was granted permission to record all lectures except the second, which was refused for unknown reasons. Perhaps the topic of "Hebraic Roots" was felt to be more sensitive in an Israeli context but, if so, it is unclear to me why, since nothing in the lecture was of a particularly sensitive nature. All other lectures were recorded and transcribed. In addition to the lectures, I draw here upon additional printed material that accompanied them, primarily Cheryl Hauer's contribution in Israel and the Church: God's Road Map (Hauer 20o6). The quotations below are from the published article. 
the discourse on the Hebraic roots of Christian faith, however, a few words on the relationship between history, authenticity, and Evangelical identity are necessary.

\section{History and Authenticity}

How history is told, not only for its own sake but also in terms of the formation of contemporary communities and identities, has been widely explored in recent decades in historical research as well as several other fields such as memory studies, narratology, and sociology. By investigating how a particular group narrates history we can also understand something about how they understand themselves and the surrounding world: the social identities that they wish to construct. From this perspective, Evangelical discourse on the Hebraic roots of Christian faith can be approached as an identity discourse that delineates authentic Christian identities from inauthentic ones, that strengthens commitment to culturally accepted moralities, and that constructs a solid historical basis for Evangelical textual ideology. By "authenticity" I follow Charles Lindholm in approaching it as a condition of purity, where "appearance" is understood to match "essence" (Lindholm 2008). Inauthenticity, on the other hand, would be a situation of symbolic manipulation where appearances are not felt to represent accurately what they are said to represent.

As was argued in Chapter One, Evangelical Zionist faith and practices take place within a polemical discourse that is centered on "symbolic manipulation" and theological fetishism. The ritualization of Israeli national symbols, the widespread use of Jewish ritual objects or "Judaica" (Feldman 2016), and the sacralization of the land have all been criticized for an inappropriate attribution of meaning to "non-Christian" objects (e.g. Ateek, Duaybis, and Tobin 2005). Similar dynamics have been observed within other evangelical contexts. John Dulin, drawing on Lindholm and Trilling (1972), has argued that the pursuit of authenticity within American Messianic Judaism is intrinsically related to modern civilization because in modernity the "widespread acknowledgement of the arbitrariness of symbols" (Dulin 2013, 36) gives rise to both an anxiety over authenticity and an urge to find it. In a similar vein, James S. Bielo has described "authenticity" as an a central "organizing trope for emerging evangelicals" within the North American context (2011, 16). As Bielo notes, there is nothing surprising about Christian movements' prizing authenticity; a return to the sources of faith has been a common organizing principle amongst new Christian movements throughout history. Yet to argue for the authenticity of one's own faith practices is a normative claim that often situates one's own community in opposition to surrounding "inauthentic" Christianities. Dulin argues that the conflicts over authenticity connected to contemporary Messianic 
Judaism in North America can be explained by a shared "evaluative grammar of authenticity" which "values causal/metonymic indexes over manipulated symbols and is undergirded by a suspicion that general appearances are symbolically manipulated in order to mask actual indexical underpinnings" $(2013,35)$. Since this (modern) sentiment is shared by both Messianic Jews and their critics, disagreement arises from their different "models of reality" (2013, 35) which guide whether a particular act of signification is understood as arbitrary (with the effect of being taken as inauthentic) or as causal/metonymic (and hence, authentic) $(2013,36)$. In order to prove authenticity an agent needs to establish a causal/metonymic link between a particular belief, practice, or symbol and its indexical underpinnings. As I argue below, a constitutive aspect of Evangelical faith is that these indexical underpinnings are strongly related to ideas about divine agency. Authentic religious practices are those that can be plausibly connected to divine intentionality either through Bible readings or personal religious experience. While certainly representing a sincerely felt need to reconnect Christianity to its Jewish roots, I argue that it is also important to view the Evangelical Zionist discourse about the Hebraic roots of faith in relation to contemporary contestations surrounding the legitimacy of Evangelical Zionist faith and practice. Thus, by employing this discourse, Christians with a "heart for Israel" are able to counter a critique of their beliefs and practices as a modern (and hence manufactured) use of symbols. Furthermore, within this discourse it becomes (ideally) possible to defend this passion for Israel without recourse to apocalyptic speculation, instead situating it in a historical trajectory that frames it as biblically authentic. At the same time, the discourse about Hebraic roots frames their opponents' beliefs and practices as constructed and, hence, unrepresentative of biblical faith.

\section{Hebraic and Greek Worldviews}

We are seven people in a small house which is surrounded by a nice little garden in the backyard of the Bridges for Peace headquarters in Jerusalem: the speaker Cheryl Hauer, five volunteers, and myself. According to the speaker, the building was originally constructed to house the queen of Ethiopia during her planned pilgrimage to Jerusalem. ${ }^{20}$ Now the BFP rents the facility from Jerusalem's Ethiopian Orthodox church which is located nearby. The room is nicely decorated in Middle Eastern style with many-colored blankets and

20 Most likely this refers to Menen Astaw who married Haile Selassie in 1911 and hence later became Queen of Ethiopia. During her exile from Ethiopia during wwI s she spent some time on pilgrimage in Jerusalem allegedly praying for the liberation of Ethiopia and promising her crown to the church when her prayers were answered. 
pillows, and lamps hanging from the low ceiling. After a short prayer, the second lecture by Cheryl Hauer begins by describing "discipleship" as a central Christian calling. Making disciples was a fundamental part of Jesus' ministry, she says, but unfortunately one that the Church has too often forgotten in its prioritization of making converts. Today, discipleship has returned to prominence in Evangelical churches and is generally recognized by many Christians as of great importance, but the problem is that most Christians do not realize that they are "building [discipleship] on the wrong foundation".21 Our notion of discipleship, according to Hauer, is derived from "Greek thinking" when it should have been based on "Hebraic thought". Hence, to understand what it really means to be a follower of Christ we must understand the "Hebraic worldview" in which Jesus was raised, lived, and worked; we need to understand the Jewishness of Jesus.

Yeshua was Jewish. He was raised in an observant Jewish home by parents who followed Jewish law and tradition; He lived in a Jewish homeland called Israel and spoke its language, Hebrew. He was a part of a robust and lively community that was identified by its active relationship with the God of Abraham, Isaac, and Jacob. He started life as all Jewish baby boys would--circumcised on the eighth day. His mother probably saved his swaddling cloths [sic], delicately embroidering them over the years, to give Him as a gift at His coming-of-age. During His first eight years of life, Yeshua would have stayed close to Mary's side, watching her as she lived the life of a committed follower of the one true God. Each Friday evening, He sat quietly as she welcomed Shabbat (the Sabbath) and laughed with glee as Joseph told and retold the stories of the forefathers. At six, He most likely began attending school at the synagogue, having already learned the aleph bet (Hebrew alphabet) from Joseph and committed many Scripture verses to memory. When Yeshua was eight, He began receiving intensive vocational instruction from His father. His life was laced with Torah (first five books of the Bible) and the teachings of the sages. He celebrated every biblical holiday and traveled to Jerusalem with His family for the pilgrim feasts. At thirteen, He may well have graduated from synagogue school to a beit midrash (school of higher learning), where He would have studied the writings of all the great Jewish teachers and debated with the sages and teachers of the Torah. Upon turning 30 ,

21 Since this lecture was not recorded and transcribed, all quotations are from my field notes unless otherwise stated. 
He went to the mikvah (place of ritual immersion) for ceremonial purification, and then stepped into His adult ministry.

HAUER 2OO6, 4-5

Even as recently as a few decades ago, this thoroughly Jewish depiction of Jesus would have been uncommon in most Evangelical circles (Kaell 2015); today, among the volunteers in Jerusalem, this understanding of "Yeshua" as completely embedded in Jewish culture and religion is rather the norm. The reevaluation of Jesus' identity in relation to his historical context is obviously not exclusive to Evangelical Christianity although it has been an important part of Evangelical, liberal as well as secular, biblical research at least since the 1800 s (commonly known among New Testament scholars as the "quest for the historical Jesus"). As an outcome of these debates, few modern exegetes would question the assertion that Jesus was Jewish, that he lived a Jewish life, and that he had some knowledge of Jewish traditions. The problem facing historians is that apart from these fundamental yet vague facts, not much else about Jesus' relationship to Jewish religious culture can be known with any certainty since there are very few historical sources apart from the accounts of the gospels.

Cheryl Hauer's narrative of Yeshua is another example of how literalists may work with intertextual gaps in order to create coherent biblical narratives amidst the "paucity of scriptural detail" (Bielo 2015, 32). This narrative of Jesus' first thirty years is constructed from a literalist position in the sense that it does not problematize the gospels as historical sources, nor the subjectivity and eclecticism of authorial accounts. But it is also noteworthy that Hauer's account adds several events and characteristics that are neither found in the gospels, nor in any other biblical text or historical source. ${ }^{22}$ This, however, is obviously beside the point since historical criticism is hardly the main purpose of the narrative. Here, as in many Evangelical reading practices, historical detail is subordinated to the power of biblical narrative and the ways in which

22 I am thinking here particularly about claims concerning the "swaddling clothes", about the Shabbat and Josef (who virtually disappears from the Gospel accounts and might have died early), that Jesus spoke Hebrew and studied at the synagogue, that he celebrated "every Jewish holiday", that he went to a Beit Midrash, and about Jesus' use of mikvah for ceremonial purification. That this characterization is historically correct is possible, in some cases perhaps even probable, but there is no way to know for sure. For more recent scholarship on the language(s) Jesus used, whether he could read and whether he had any formal theological training see (Keith 2011, 2014). For more on the type of Judaism that was practiced during Jesus' life see (Sanders 1992). My sincere thanks to Magnus Zetterholm and Dan Nässelqvist for information and discussion about recent New Testament scholarship on the historical Jesus. 
this narrative can be put to theological, moral, or spiritual use today. Thus, the account of Jesus as thoroughly embedded in Jewish religious culture should be read as a narrative primarily directed towards modern concerns. As such, it provides a historical basis for modern Evangelicals' identification with the land of Israel — "a Jewish homeland called Israel" — as well as with Jewish symbols and practices (circumcision, Torah study, ritual purification, Jewish holidays). If Jesus was completely Jewish, these practices must be legitimate for modern Evangelicals too; optional perhaps, but certainly acceptable and valid expressions of Evangelical religiosity.

Furthermore, by describing Jesus' early years as thoroughly situated in a Jewish religious culture, Hauer is able to explain what is wrong with the notion of discipleship that present-day Christians have inherited from Christian tradition: it comes embedded in a Greek worldview rather than the Hebraic worldview in which it originated. When Jesus called his disciples, and later commanded them to "make disciples" of all peoples, he did so from his Hebraic understanding of discipleship, not from the Greek, which was added later by the Church Fathers. In other words, the "essence" of discipleship can only be found within a Hebraic symbolic universe. It is important to note here-in light of historical research into conservative Evangelical and fundamentalist polemic against "higher criticism" in the early twentieth century (Balmer 1993, Marsden 1991, 2006) — that Cheryl Hauer's argument in this discourse is that Jesus' historical context needs to be understood in order to understand his message, not that the context of the authors of the gospels needs to be taken into account in order to understand their portrayal of Jesus.

What then, is the problem with the Greek worldview? In what ways has its influence severed the link between contemporary manifestations of Christianity and authentic biblical beliefs and practices as "originally" conceived? In the 2006 article that the lecture builds upon, and in several of the lectures in the foundational teaching series, Greek culture is identified with theological, hermeneutical, and ideological modifications of Christianity: changes that are felt to be antithetical to authentic Christianity. According to Hauer, the start of this process can be dated quite precisely to the early Alexandrian church.

The first Christian school of theology was established in Alexandria, and the immediate task became the mingling of Greek philosophy with the Bible. Literal interpretation of Scripture gave way to allegory, opening the door to a myriad of heresies, among them Christian anti-Semitism. The vibrant personal and community relationship between the early church and the God of Abraham, Isaac, and Jacob became intellectualized and systematized Christian doctrine. By the third century, this Hellenization 
of the Church helped to tear Christianity away from its Judaic root and create a chasm between Christians and Jews that would remain for 1,700 years.

HAUER 2OO6, 7

The Greek worldview, and the influences it has had on Christian tradition, is understood as historically contingent additions that human agents have made to biblical religion. In other words, through its abstraction of the biblical message, Greek philosophy represents a symbolic manipulation of the transcendental meaning contained within the text. The "chasm between Christians and Jews" is also the chasm between "the Bible" and "tradition", and between the essence of Christian symbols and practices and their appearances in the modern day Church. When Christianity was mixed with Greek philosophy it became detached from its roots in Jewish culture, and the "vibrant and personal community relationship" with God that was at the heart of Jesus' message gave way to an abstract, intellectualized, and allegorized form of Christianity. It is this detached form of Christianity that is responsible not only for theological liberalization but also for "a myriad of heresies" including replacement theology and Christian anti-Semitism.

There is much of interest in this portrayal of the Greek influence on Christianity. Scholars of early Christianity would hardly question that Greek culture and philosophy has had a significant impact on the development of Christianity, but while the extent and precise content of this influence is debatable, few would recognize a strict separation between Hebraic and Greek worldviews, and would rather argue that the entanglement between the two cultures is both much more profound and of an earlier date than Hauer's account would have it. More importantly, most biblical scholars would claim that the Greek influence is visible not only in Christian history and tradition but also within the very biblical text itself, particularly in Johannine and Pauline theology (e.g. Breytenbach 2015). The extent to which Hebraic and Greek "worldviews" influenced the authors of the Bible, the early Jesus movement, and even Jesus himself is still very much discussed, but that both cultural systems had an impact on all these features we probably can say for sure.

But what is more important about this discourse for my purposes is what it says about the relationship between the Bible, tradition, and the preferred form of Christianity in the present. The characterization of Hebraic vs. Greek thought to a large extent circles around a conceptual dichotomy between proximity and distance that is reminiscent of more contemporary Evangelical debates about Christianity and surrounding culture. The "Hebraic worldview" corresponds to an ideal Evangelical culture with its focus on direct and 
unmediated access to the divine, on intimacy, and on community (Bielo 2008, Luhrmann 2004, 2012, Moberg 2013). Hebraic thought is described as fundamentally theocentric and monotheistic, in contrast to all the surrounding ancient cultures including the Greek. The main critique here is not towards the polytheism of ancient culture-although this is mentioned as well-but rather towards anthropocentrism. The Greeks, we are told, placed "man at the center of all things"; they "venerated the human body"; preferred "individuality"; and they "sought knowledge" not in order to know God as the Hebrews did but rather "for the sake of knowledge alone" (Hauer 2006, 10-11).

Furthermore, in Hauer's description, the Hebraic worldview fostered personal and intimate relationships with God, a strong supportive community, a direct and literal reading of the Scripture, and an integrated faith that pervaded all parts of life. The Greek worldview, on the other hand, is identified with terms that signal a distance: allegory, intellectualization, systematization, and Christianity's rupture from its roots. This dichotomy of proximity and distance is related to what was discussed in terms of "the problem of presence" in the previous chapter (Engelke 2007); in other words, the distance associated with Greek culture is understood as a separation from divine presence. Hebraic culture, on the other hand, is seen to represent authentic biblical faith, which makes it able to mediate divine presence in a way that the artificiality of Greek culture, and its accompanying theological and cultic developments, are unable to do. In the historical narrative of the Hebraic roots of Christian faith the development of allegorical exegesis, replacement theology, and Christian anti-Semitism are understood in the light of this detachment from God's presence: as a movement of increasing distance between Christian culture and authentic Christianity. Human symbolic manipulation (i.e. church tradition) separated Christianity from its source. Christian anti-Semitism, particularly as it was enacted in the Holocaust, is the ultimate outcome of this separation.

\section{Purification}

In Hauer's discourse "Hebraic" and "Greek" semiotic content is incommensurable; as with Rachel's search for a more Jewish form of Christianity (referenced towards the beginning of this chapter), the disentanglement of the Greek influence upon Christianity here is an act of purification in the search for authenticity. In Dulin's above-mentioned article he draws attention to a similar production of authentic biblical faith among members of the Messianic Jewish community that he studies. He also, I believe rightly, connects this tendency to the modern preoccupation with "purification" (Keane 2007, Latour 1993, see also: Bialecki 2014b). The Greek influence in Hauer's discourse, in contrast to the Hebraic, is understood as socially conditioned and man-made, 
in other words, manufactured. The human agency implicit in the influence of Greek material in Christian tradition evidences a manipulation of symbols that makes beliefs and practices allegedly derived from Greek thought inauthentic by definition. In comparison to the discussion about human and divine agency in Chapter Three it is interesting to note that a similar thought pattern underlies both the discussion of the Hebraic roots and the Christian calling. Authentic religious expression is attained by locating divine agency and by placing human "agency in abeyance" (Miyazaki 200o); being able to rhetorically link a particular belief, practice, or symbol to divine intent guarantees its authenticity. Where divine agency is located, and how this origin is tested, naturally varies within different strands of contemporary Evangelicalism. While Pentecostal/charismatic churches tend to place a high value on personal religious experiences, more fundamentalist forms of Evangelicalism generally consider the Bible the final arbiter of authenticity (Bialecki 20og). Since the Evangelical culture in Jerusalem incorporates people from different denominational and theological backgrounds both the Bible and personal religious experience play a role in their validation of religious authenticity. In Chapter Three it was discussed how a calling often underwent a discernment process which could involve prayer, conversations with friends, and bible studies. Similar methods are also applicable here: practices, traditions, and beliefs that cannot plausibly be argued to have a biblical origin are deemed inauthentic and hence subject to the purification process. Among the volunteers it is common to question "pagan" Christian holidays and un-biblical Christian belief and practices. Sara, for instance describes how the Church has adopted these pagan customs and beliefs and how realizing this was a major turning point in her religious life.

Well, realizing that Christianity is actually from Jewish roots we [Sara and her husband] also saw that the Christian world was pagan in a lot of practices. So in the study of Scriptures we saw that God never did away with His feast days. We saw ... that Christian[s] needed to govern their lives by the appointed times of the Lord and not turn towards the paganism that Constantine took to the Church. You know, Easter and Christmas and Santa Claus and those kinds of things. But to also teach the Church ... that Christ fulfilled the Law and that He didn't do away with the Law.

As was discussed in Chapter Three, the movement of the religious self towards a Judeo- or Israel-centric form of Christianity is often construed as a form of conversion experience, and it is often associated with a deeper and more profound study of the biblical Scriptures. For Sara, this realization of Christianity's Jewish roots led to a reassessment of the theological and cultic heritage of the 
Church and a search for a different form of Christianity that is disentangled from this baggage. Whether Bible study is a "method" in this disentanglement or rather a post-facto rationalization of a previous movement of the religious self is difficult to know; nonetheless, it is safe to say that the volunteers often associate the purification of Christianity with a return to biblical faith. To my knowledge, however, few volunteers go all the way in their reformation of religious practices: despite criticizing the paganism of the Church and celebrating Jewish forms of religious life, it is quite uncommon to meet Evangelicals who strictly adhere to biblical Sabbath commandments, for instance, or refrain from eating food which is prohibited in the Hebrew Bible. Rachel, whose husband is a Messianic Jewish Israeli, is one such, but even in her case and in spite of her insistence on the need to return to the Jewish roots of faith, a cab was deemed an appropriate means of transport to get to the conference on a Friday evening. While eclectically practiced and understood, however, the return to biblical faith is of prime concern among the volunteers, not only for the individual but for the Church as a whole. As for Sara, quoted above, purifying Christianity of the Greek philosophical heritage is perceived as the responsibility of all who call themselves Christians: purification is understood as reform.

\section{A Vanguard of Reform}

Interest in the Hebraic roots of Christian faith is shared by both gentile and Jewish believers within Messianic Judaism and Evangelical Zionism. While much previous literature has approached Messianic Judaism as a marginal and controversial branch of Judaism (e.g. Cohn-Sherbok 2000, Feher 1998), I believe Hillary Kaell is right in identifying the gentile majority of the movement with "born-again seeking" $(2015,42)$. In Kaell's account these born-again seekers are characterized by an appetite for spiritual growth and they understand their affiliation to Messianic Judaism as part of an "ongoing commitment to biblical study, prophetic theology, or a relationship with Jesus" (47). Volunteers in Jerusalem often also explain their involvement with Messianic congregations and their interest in Jewish (alternatively "Judaic" or "Hebraic") religious forms in terms of personal religious development and as a way to deepen and enrich their religious lives. Yet the analysis here has demonstrated that contemporary discourses about the Hebraic roots of Christian faith in Jerusalem also serve broader ideological interests: they provide a historical narrative that posits contemporary Evangelical identification with Judaism and Israel as an expression of authentic biblical faith as opposed to other forms of Christianity that are interpreted as passive receptacles of man-made traditions. Thus, this narrative is also an important part of an argument in an ideological debate about the truth of different forms of Christianity, their 
connected (and differing) textual ideologies, and the theological legitimacy of the religious symbolification of the land — and the State—of Israel that is central to contemporary Christian Zionism.

Pierre Bourdieu argued in Practical Reason that this usage of history is a feature of particular importance in groups that challenge the reigning hegemony within any particular cultural genre or social context. To challenge the very foundations of a discourse or a genre often requires, at least in practice, a return to the sources from which a new interpretation can be made and legitimacy be acquired (Bourdieu 1995 [1994]). Approached from this perspective, Christian Zionism in Jerusalem can be seen as a movement that is bent on religious reform, on challenging what is perceived as the reign of theological liberalism and allegorical interpretations within the Church. In many ways, this is also precisely the way the volunteers and the ministries in Jerusalem understand themselves: as the vanguard of a reform movement that is biblicallycentered, Israel-loving, and unmarked by centuries of anti-Jewish theologies.

There's such a move of God right now out ... in Latin America, Africa, and Asia and these are people, they don't have the Scofield Bible, you know, they don't have so much the Dispensational teaching. They don't know, they've never met a Jew, they don't know much about the history of persecution of Jews in Europe at all. They just have their Bible, the Holy Spirit. It opens to them, this revelation that God is involved in the restoration of Israel, and the doors that are opening to us in a lot of these countries, it's quite amazing.

This global imaginary, here expressed by David Parsons, is central to the sense of confidence and reform that permeates the ministries' work in Jerusalem. The most significant part of this reform takes place not in the Western countries but in the Global South; in the view of the ministries this development is connected to the charismatization of Global Christianity. In Chapter Three I stressed that divine agency coupled with "the plain reading of the Bible" are understood as the central explanatory factors in the realization of Israel's spiritual significance. Since the teachings of the Church-including that in many Evangelical and charismatic churches - are bearers of a theological and philosophical tradition that hides the simple truth that lies in the Bible, the Southern Churches' paucity of Western tradition is understood to enable and make space for divine agency to be enacted in Bible reading practices.

The authentic Christian faith that would be the outcome of such a reversal would be Bible-centered, purified from centuries of Greek theological and philosophical influences, and have a central symbolic role reserved for Israel. 
In the ministries' view, this would constitute a return to early Christianity as it was meant to be prior to the Hellenization process and the so-called "parting of the ways" between Judaism and Christianity. The logics of this return rely on a grammar of authenticity that not only prioritizes causal/metonymic connections over symbolic manipulation but also divine over human agency. Israel is at the heart of this reversal of the Christian gaze: as an index of authenticity and divine agency, Israel is the catalyst of this act of purification.

\section{Conclusions}

As in considerable previous research on contemporary Christian Zionism I have here paid extensive attention to the relationship between biblical literalism, Bible prophecy and Evangelical understandings of the State of Israel. This exploration began with a discussion about the relationship between literalism and Christian Zionism where it was argued that a linear causality that explains Christian Zionist views of Israel as derivative of literalist readings of Biblical prophecy both misrepresents Christian Zionists' engagements with the biblical text and misconstrues Christian Zionists' religious symbolification of the State of Israel.

I have here argued for a partial reversal of this causality. It is not simply that Israel's theological significance is dependent on literal readings of biblical prophecies but also that the symbolification of Israel authenticates particular Evangelical reading practices. When the "Evangelical gaze" is allowed to structure the experience of Israel, not only prophecy beliefs are felt to be validated but also, significantly, a particular Evangelical textual ideology. In other words, Israel as a religious symbol is important for the Evangelicals in Jerusalem not primarily because it is the outcome of a specific textual process but more so because Israel has become entangled in the very machinery of Evangelical textual ideology. Within this ideology, Israel serves as an index of divine intentionality as well as biblical authenticity. It is the material symbol through which Evangelical literalist ideology makes sense. 